\title{
Krzysztof Malicki
}

Uniwersytet Rzeszowski, Instytut Nauk Socjologicznych

https://orcid.org/0000-0002-2628-4705

kmalicki@ur.edu.pl

\section{Pomiędzy niepamięcią a pamięcią ekskluzywną. Współczesny Rzeszów wobec swojej żydowskiej przeszłości}

\begin{abstract}
Streszczenie
Rzeszów należy do tych polskich miast, które przed wojną charakteryzowały się obecnością dużej, dynamicznie rozwijającej się społeczności żydowskiej, unicestwionej następnie niemal całkowicie w wyniku Holokaustu. Po drugiej wojnie światowej żadne inne miasto w Polsce nie doświadczyło podobnej skali społeczno-przestrzennych zmian i dynamicznego rozwoju. Żydowskie życie, które do 1939 r. było niedającym się przeoczyć elementem przestrzeni miejskiej, dziś nie istnieje, a pozostałe po nim materialne ślady są słabo identyfikowane przez współczesnych mieszkańców i funkcjonują na absolutnym marginesie ich zbiorowej pamięci. Niniejszy artykuł podejmuje problem dysproporcji między bogactwem historii Żydów rzeszowskich i dramatu ich Zagłady w okresie wojny, a rozmiarami współczesnej pamięci o nich w świadomości dzisiejszych mieszkańców Rzeszowa. Tekst analizuje historię procesów symbolicznego naznaczania przestrzeni miejskiej pod kątem pamięci o żydowskich mieszkańcach i różnorodne formy upamiętniania Holokaustu w okresie powojennym. Informacje te zostają jednocześnie skonfrontowane z realizowanymi cyklicznie badaniami świadomości historycznej i pamięci zbiorowej na reprezentatywnych, sondażowych próbach mieszkańców Rzeszowa.
\end{abstract}

\section{Słowa kluczowe}

Rzeszów, Holokaust, pamięć zbiorowa, upamiętnienie

\begin{abstract}
Rzeszów belongs to this specific group of Polish cities which before the war were characterised by a large and dynamically developing Jewish community, which was then almost completely annihilated in the Holocaust. After World War II, no other city in Poland experienced a similar scale of socio-spatial changes and dynamic development. Jewish life, which until 1939 was a very visible element of urban space, does not exist today, and its remaining material traces are poorly identified by modern residents and are located on the absolute margins of their collective memory. This article deals with the problem of the disproportion between the rich history of Rzeszów Jews and their annihilation during the war, and the contemporary memory of them of today's residents. The text analyzes the history of the processes of symbolic commemoration of Jewish inhabitants and various forms of commemorating the Holocaust in the post-war period. This data is simultaneously confronted with regularly carried out research on historical awareness and collective memory on representative survey samples of the inhabitants of Rzeszów.
\end{abstract}

\section{Key words}

Rzeszów, Holocaust, collective memory, commemoration 
Charakterystyczną cechą refleksji poświęconej żydowskiej historii na obszarze dzisiejszych ziem Polski jest znacząca dysproporcja między dynamicznym rozwojem studiów nad życiem i zagładą Żydów a skalą społecznej pamięci o tej unicestwionej w okresie wojny mniejszości narodowej. Mimo systematycznego wzrostu liczby publikacji popularnonaukowych oraz faktu, że najważniejsze miejsca Zagłady polskich Żydów zostały z czasem upamiętnione w postaci placówek muzealnych lub miejsc pamięci, badania społeczne ukazują nadal duże obszary społecznej amnezji, a nierzadko wręcz pamięci usytuowanej w opozycji do faktograficznej wiedzy o historii Żydów i nacechowanej wyjątkowo dużą ilością uprzedzeń i stereotypów ${ }^{1}$. „Można powiedzieć - pisze o zamieszkujących niegdyś Polskę Żydach Sławomir Kapralski - że są oni upamiętniani, ale nie pamiętani"2. Co więcej, jak pokazują sondaże prowadzone przez ośrodki badań społecznych przez ponad siedem dekad od chwili zakończenia wojny, niewiele pod tym względem się zmieniło, a ewentualne przekształcenia pamięci Polaków dokonują się bardzo wolno ${ }^{3}$. „Wojenne zniszczenia w sferze pamięci - zauważa Antoni Sułek - jeszcze nie zostały usunięte, wciąż jesteśmy w okresie powojennego «sprzątania»"4.

Przedmiotem analizy w tym artykule jest pamięć mieszkańców Rzeszowa o społeczności Żydów zamieszkujących miasto do 1945 r. W 1939 r. Rzeszów był niespełna 40 -tysięcznym miastem powiatowym na wschodnich peryferiach województwa lwowskiego. Żydzi stanowili wówczas trzecią część jego mieszkańców, silnie oddziałując na lokalne życie polityczne, gospodarcze i kulturalne. Niemiecka okupacja zmieniła pod tym względem wszystko. W 1945 r. Rzeszów awansował na stolicę nowego województwa rzeszowskiego. U schyłku tego roku

${ }^{1}$ Rosa Lehmann, Symbiosis and Ambivalence. Poles and Jews in a small Galician Town, Oxford-New York: Berghahn Books, 2001; Shimon Redlich, Razem i osobno. Polacy, Żydzi, Ukraińcy w Brzeżanach 1919-1945, tłum. Grzegorz Godlewski, Sejny: Pogranicze, 2002; Joanna Tokarska-Bakir, Legendy o krwi. Antropologia przesq̨du. Warszawa: Wydawnictwo W.A.B., 2008; Antysemityzm, Holokaust, Auschwitz w badaniach społecznych, red. Marek Kucia, Kraków: Wydawnictwo Uniwersytetu Jagiellońskiego, 2011; Krzysztof Malicki, Poza wspólnota pamięci. Życie i Zagłada Żydów w pamięci mieszkańców regionu podkarpackiego, Warszawa: Wydawnictwo IFiS PAN, 2017; Jacek Nowak, Sławomir Kapralski, Dariusz Niedźwiedzki, On the banality of forgetting: tracing the memory of Jewish culture in Poland, Berlin: Peter Lang, 2018.

${ }^{2}$ Sławomir Kapralski, Żydzi i zagłada w polskich kulturach pamięci: między antagonizmem i agonem, „Teksty Drugie” 2016, nr 6, s. 354.

${ }^{3}$ Piotr T. Kwiatkowski, Lech M. Nijakowski, Barbara Szacka, Andrzej Szpociński, Między codziennościq a wielka historiq̨. Druga wojna światowa $w$ pamięci zbiorowej społeczeństwa polskiego, Gdańsk-Warszawa: Muzeum II Wojny Światowej, Wydawnictwo Naukowe Scholar, 2010; Antoni Sułek, Zwykli Polacy patrzq na Żydów. Postawy społeczeństwa polskiego wobec Żydów w świetle badań sondażowych (1967-2008) [w:] Następstwa zagłady Żydów. Polska 1944-2010, red. Feliks Tych, Monika Adamczyk-Garbowska, Lublin: UMCS, Żydowski Instytut Historyczny, 2011.

${ }^{4}$ Antoni Sułek, Badacz i świadek drugiej generacji. O ratowaniu lokalnej pamięci zagłady Żydów, „Więź” 2017, nr 4 (670), s. 74. 
nie było w nim już jednak ani Żydów, ani żadnej zachowanej w nienaruszonym stanie materialnej pamiątki po ich obecności. W późniejszym okresie PRL Rzeszów uformował się jako zupełnie nowy byt społeczno-przestrzenny, z olbrzymią przewagą ludności napływowej i rozrastający się na okoliczne tereny. Po niełatwych pierwszych latach transformacji, współczesne, niemal 200-tysięczne miasto weszło w nowy okres dynamicznego rozwoju i u progu trzeciej dekady XXI w. zaliczane jest do niewielkiego grona polskich miast wojewódzkich z prognozowanymi szansami na dynamiczny rozwój. Wydawać by się zatem mogło, że problematyka pamięci (zwłaszcza o żydowskiej społeczności, która przez wieki określała charakter tego miasta), i w ogóle spoglądania w przeszłość, to temat niezbyt istotny i nieinteresujący w przypadku miasta, które kładzie szczególny nacisk na nowoczesność i postęp, a w swojej promocji określa się wręcz mianem „stolicy innowacji”. Tymczasem podjęcie tego tematu wydaje się ważne właśnie z powodu owej zaskakująco dużej dysproporcji między „historycznym podłożem", które ukształtowało miejski organizm Rzeszowa, a miejscem tej przeszłości w dzisiejszej perspektywie symbolicznego kształtowania przestrzeni miejskiej i formowania tożsamości mieszkańców, zawsze silnie związanej z pamięcią zbiorową ${ }^{5}$.

Niniejszy artykuł stara się odpowiedzieć na pytanie, jakie miejsce zajmują Żydzi i ich przeszłość w pamięci współczesnych mieszkańców Rzeszowa. Aby znaleźć odpowiedź na tak zadane pytanie, nie ograniczono się jedynie do analizy istniejących w przestrzeni miejskiej miejsc pamięci oraz obrzędów i uroczystości nawiązujących do unicestwionej przeszłości rzeszowskich Żydów. Przez cykl szeroko zakrojonych badań sondażowych na reprezentacyjnych próbach mieszkańców miasta zrealizowanych w 2010 i 2015 r., „oficjalną” pamięć wyrażoną w pomnikach i nazwach ulic skonfrontowano z „pamięcią potoczną” jej mieszkańców. Zastosowana w ten sposób triangulacja technik badawczych pozwala na spojrzenie na pamięć analizowanej zbiorowości z różnych perspektyw. Ukazując meandry polityki upamiętniania na przestrzeni kilkudziesięciu lat, zderza ją finalnie ze stanem współczesnej świadomości lokalnej wspólnoty i jej wrażliwością na żydowską przeszłość.

Próba odpowiedzi na pytanie, czym jest społeczna pamięć przeszłości (pamięć zbiorowa), nastręcza licznych trudności, które na wstępie wymagają definicyjnego uporządkowania. Dostrzegając uwikłanie refleksji nad tą problematyką w domeny badawcze historii, socjologii i psychologii, Jacques le Goff zauważył trafnie, że „Pojęcie pamięci jest usytuowane na skrzyżowaniu dróg”.

\footnotetext{
${ }^{5}$ Artykuł jest zmodyfikowaną i uaktualnioną wersją badań zrealizowanych przez autora i zaprezentowanych w monografii: Krzysztof Malicki, 70 lat po Zagładzie. Przeszłość Żydów w pamięci zbiorowej mieszkańców Rzeszowa, Rzeszów: Wydawnictwo Uniwersytetu Rzeszowskiego.

${ }^{6}$ Jacques Le Goff, Historia i pamięć, tłum. Anna Gronowska, Joanna Stryjczyk, Warszawa: Wydawnictwa Uniwersytetu Warszawskiego, 2007, s. 101.
} 
Rozbieżności metodologiczne i definicyjne, wręcz „pojęciowy i terminologiczny chaos"7 powodują, że podejmując temat pamięci, badacze czynią czasami głównym przedmiotem badań stan wiedzy o przeszłości wyrażony znajomością dat i faktów z przeszłości (w takim ujęciu stosowane jest pojęcie świadomości historycznej) lub w upamiętnionych na różne sposoby przestrzeniach symbolicznych. Jeszcze dla innych pamięć to zjawisko ze sfery komunikacji społecznej - rozmowy o przeszłości, czynne akty komemoracji, w nawet najdrobniejszych formach, o ludziach lub wydarzeniach z przeszłości. Niewątpliwie pamięć jest zjawiskiem wielowymiarowym i jak definiuje ją Barbara Szacka, składają się na nią dwa zasadnicze elementy. Pierwszym są „wyobrażenia” o przeszłości grupy, drugim zaś różnorodne formy upamiętniania przeszłości (głównie postaci i wydarzeń) $)^{8}$.

Mówiąc o pamięci zbiorowej (społecznej), w niniejszym artykule odwoływać się będę do powyższej definicji Szackiej. Sygnalizuje ona bowiem wyraźnie to, że pamięć przejawia się niejednorodnie i nie zawsze w sposób spójny, na różnych płaszczyznach aktywności społecznej. Czasami to, co trwa w świadomości ludzi, nie może być z różnych względów upamiętnione. Nierzadko to, co utrwalone $\mathrm{w}$ przestrzeni symbolicznej, nie jest identyfikowane i rozpoznawane przez tych, którzy żyją obok tych upamiętnień. Zapewne żaden element polskiej historii nie funkcjonował na podobnych rozdrożach, jak właśnie pamięć o Żydach, ich życiu i Zagładzie, a przez niemal cały okres komunizmu pamięć o nich była dodatkowo przedmiotem daleko idących manipulacji ${ }^{9}$.

Mówiąc o pamięci zbiorowej, zawsze należy określać, czyją pamięć badamy, oraz jakie jej elementy poddajemy analizie. Istnieje wiele wymiarów pamięci i inny jej obraz uzyskamy, próbując opisać pamięć zbiorową wszystkich Polaków, a inny, gdy przedmiotem badania stanie się pamięć mniejszych, regionalnych i lokalnych wspólnot. Inny obraz pamięci wyłoni się, kiedy poddamy analizie materialne upamiętnienia w postaci pomników lub nazw ulic, inny zaś gdy odwołamy się do świadomości mieszkańców danego obszaru, dla których przestrzenie symboliczne mogą być niedostrzeganym i obojętnym elementem codziennego krajobrazu. Nierzadko uzyskane w ten sposób informacje będą się diametralnie różnić. Upamiętnienie jakiegoś wydarzenia w postaci pomnika nie znaczy, że wszyscy mający z tym pomnikiem kontakt przyswoją sobie i uświadomią jego przesłanie oraz sens. Inny obraz pamięci otrzymamy, badając elity społeczne, inny - zwyczajnych obywateli.

${ }^{7}$ Barbara Szacka, Czas przeszły, pamięć, mit. Warszawa: Wydawnictwo Naukowe Scholar, 2006, s. 33.

${ }^{8}$ Eadem, Pamięć społeczna [w:] Encyklopedia Socjologii, Warszawa: Oficyna Naukowa, 2000 , s. 52.

${ }^{9}$ James E. Young, The Texture of Memory. Holocaust, Memorials and Meaning, New Haven London: Yale University Press 1993, s. 113 i n. 


\section{Dziedzictwo historii i materialne pamiątki, które przetrwały}

Próba dokonania zarysu dziejów Rzeszowa pomijająca wkład społeczności żydowskiej w rozwój miasta jest praktycznienie niemożliwa, mimo że w przeszłości nierzadko podejmowano takie usiłowania ${ }^{10}$. Początek obecności Żydów w Rzeszowie sięga prawdopodobnie XVI w. ${ }^{11}$, choć istnieją przesłanki, by sądzić, że mogli oni być $w$ mieście znacznie wcześniej ${ }^{12}$. Z pewnością już od przełomu XVI i XVII w. znaczący i systematycznie rosnący był wkład Żydów w rozwój rzeszowskiego rzemiosła i handlu, a pod koniec XVIII w. ludność żydowska stanowiła prawie połowę mieszkańców miasta. W tym czasie w Rzeszowie powstały dwie murowane synagogi, które przetrwały po dziś dzień (tzw. synagoga staromiejska oraz nowomiejska) ${ }^{13}$. W okresie zaborów Rzeszów - „galicyjska Jerozolima"14 - ze względu na peryferyjne położenie nie odgrywał znaczącej roli jako niewielkie miasto powiatowe. Przez niemal cały wiek XIX Żydzi stanowili nadal większość jego mieszkańców. Tak duży ich udział wśród ogółu mieszkańców oznaczał konieczność tworzenia wielu miejsc obsługujących tę społeczność w wymiarze religijnym, kulturalnym i gospodarczym. Żydowskie synagogi, domy modlitwy, sklepy, mykwy czy rzezaki określały w znacznej mierze miejski pejzaż. Społeczność integrowała żydowska gmina wyznaniowa, kahał, choć w samej społeczności istniały silne podziały i zróżnicowanie, majątkowe i religijne ${ }^{15}$. W okresie Drugiej Rzeczypospolitej Żydzi stanowili około 40 procent mieszkańców Rzeszowa ${ }^{16}$. Zajmowali się głównie rzemiosłem i handlem. Byli także aktywni w lokalnej polityce, dysponując w 1934 r. 15 z 35 mandatów

${ }^{10}$ Działo się tak zwłaszcza w okresie PRL, kiedy w publikacjach o Rzeszowie największy nacisk kładziono na robotniczo-chłopskie, „rewolucyjne tradycje” regionu i nowo powołanej stolicy województwa, a w okresie okupacji na działalność podziemną Polskiej Partii Robotniczej. W niektórych publikacjach o Rzeszowie nie wspominano o Zagładzie Żydów nawet jednym słowem. Zob. Rzeszów, Kraków: Wydawnictwo Artystyczno-Graficzne, 1965, s. 22.

${ }^{11}$ Podstawą wyznaczenia tego okresu na podstawie wzmianki o odnalezieniu żydowskiej tablicy nagrobnej z 1553 r. (Wacław Wierzbieniec, Z dziejów gminy żydowskiej w Rzeszowie, „Prace Historyczno-Archiwalne”, 1995, t. 3, s. 79).

${ }^{12}$ Według niektórych źródeł obecność Żydów w Rzeszowie datowana jest przed $1340 \mathrm{r}$. Zob. Rzeszów [w:] red. Shmuel Spector, Geoffrey Wigoder, Elie Wiesel, The Encyclopedia of the Jewish Life before and during the Holocaust, t. 2, New York: New York University Press, 2001, s. 1111.

${ }^{13}$ Robert Witalec, Historia Żydów Rzeszowskich od XVI wieku do 1944 roku, „Prace Historyczno-Archiwalne", 1993, t. 1, s. 65-66.

${ }^{14}$ Pojęcia tego użył Samuel Bredetzky w swoich pamiętnikach z podróży po Galicji, zob. Stanisław Schnür-Pepłowski, Galiciana 1772-1812, Lwów: Księgarnia H. Altenberga, 1896, s. 153.

${ }^{15}$ Witalec, Historia Żydów Rzeszowskich od XVI wieku do 1944 rok... s. 66-69.

${ }^{16}$ Wacław Wierzbieniec, Rzeszów [w:] The Yivo Encyclopedia of Jews in Eastern Europe, red. Gershon David Hundert, t. 1, New Haven-London, Yale University Press 2008, s. 1642. 
w Radzie Miasta. W tym czasie miasto opuściło około 600 młodych Żydów, którzy wyjechali do Palestyny w ramach ruchu syjonistycznego ${ }^{17}$.

Życie Żydów w Rzeszowie w okresie okupacji niemieckiej w latach 19391944 przebiegało w rytmie właściwej dla całego Generalnego Gubernatorstwa polityki „ostatecznego rozwiązania”. Zapowiedzią całkowitej eksterminacji stało się narastanie polityki segregacji, dewastacji żydowskich miejsc kultu i początkowo dość chaotycznego terroru. Oznakowanie żydowskich sklepów, a zaraz potem i samych Żydów, nałożenie na nich pracy przymusowej, stopniowe ograniczanie miejsc pobytu aż po wprowadzenie kary śmierci dla opuszczających teren getta, to kamienie milowe tej polityki. Zamknięcie rzeszowskiego getta nastąpiło na przełomie grudnia 1941 i stycznia $1942 \mathrm{r}$. W mieście skoncentrowano wówczas ludność z mniejszych okolicznych gett ${ }^{18}$.

Najbardziej dramatyczny akt zagłady Żydów rzeszowskich nastąpił latem i jesienią $1942 \mathrm{r}$. W wyniku kilku akcji deportacyjnych przeprowadzonych w lipcu, sierpniu i październiku około dwie trzecie żydowskiej ludności getta zostało deportowane do ośrodka natychmiastowej zagłady w Bełżcu ${ }^{19}$. Tysiące osób, zwłaszcza chorych i starych, rozstrzelano w lasach pod Głogowem Małopolskim. Na terenie pomniejszonego getta, będącego obozem pracy przymusowej, pozostało około 4-6 tysięcy oczekujących na swój los niewolniczych pracowników. Ostateczna likwidacja getta nastąpiła we wrześniu 1943 r., a jego mieszkańców wysłano do obozów Auschwitz-Birkenau oraz Szebnie. I tym razem wywózkom towarzyszyły masowe egzekucje w podgłogowskich lasach. Ostatnie pozostałe $\mathrm{w}$ mieście komanda robocze porządkujące teren getta i zatrudnione $\mathrm{w}$ fabryce silników lotniczych wywieziono do obozów w lipcu 1944 r., tuż przed wyzwoleniem miasta ${ }^{20}$. Liczba ofiar jest dziś trudna do oszacowania. Tylko $\mathrm{w}$ lipcu 1942 r. deportowano do Bełżca około 16,5 tysiąca ludzi ${ }^{21}$. Niemiecka okupacja doprowadziła do unicestwienia żydowskiej społeczności Rzeszowa. Wojnę prze-

${ }^{17}$ Wacław Wierzbieniec, $Z$ dziejów gminy żydowskiej w Rzeszowie, „Prace Historyczno-Archiwalne" 1995, t. 3, s. 86-88.

${ }^{18}$ Zbigniew K. Wójcik, Rzeszów w latach drugiej wojny światowej. Okupacja i konspiracja 1939-1944-1945, Rzeszów-Kraków: Instytut Europejskich Studiów Społecznych, 1998. s. 144-145, 151-153; Samuel Fishman, Martin Dean, Rzeszów [w:] Encyclopedia of Camps and Ghettos 1933-1945, t. 2: Ghettos In German-Occupied Eastern Europe, red. Martin Dean, Mel Hecker, Bloomington-Indianapolis: United States Holocaust Memorial Museum, Indiana University Press, 2012, s. 567.

${ }^{19}$ Rola obozu w zagładzie rzeszowskich Żydów: Robert Kuwałek, Obóz zagłady w Bełżcu, Lublin: Państwowe Muzeum na Majdanku, 2010.

${ }^{20}$ Shmuel Krakowski, Rzeszów [w:] Encyclopedia of the Holocaust, red. Israel Gutman, New York-London: Macmillan Publishing Company, Collier Macmillan Publishers, 1990, t. 3, s. 1315; Tadeusz Bieda, Eksterminacja Żydów w Rzeszowie w latach 1939-1944, „Prace Historyczno-Archiwalne" 1993, t. 1, s. 155-158.

${ }^{21}$ Elżbieta Rączy, Zagłada Żydów w dystrykcie krakowskim w latach 1939-1945, Rzeszów: Instytut Pamięci Narodowej - Uniwersytet Rzeszowski, 2014, s. 297-299. 
żyło 700-800 rzeszowskich Żydów, z czego około 600 w ZSRR 22 . Latem 1945 r. w mieście było 287 Żydów ${ }^{23}$. W wyniku antysemickich rozruchów w czerwcu 1945 r. (rezultat podejrzeń o dokonanie mordu rytualnego na dziecku) ostatni ocalali opuścili miasto, zamykając tym samym liczący cztery wieki rozdział obecności Żydów w Rzeszowie ${ }^{24}$.

W okresie okupacji nie tylko dokonano eksterminacji rzeszowskiej społeczności żydowskiej, doszło także do niemal całkowitej dewastacji miejsc, które przed wojną stanowiły jej wizytówkę oraz świadectwo religijno-kulturalnego wkładu w życie organizmu miejskiego. Największa skala zniszczeń dotknęła niewątpliwie oba cmentarze żydowskie.

Najstarszy z nich, zlokalizowany nieopodal Rynku w centrum dzisiejszego miasta (pl. Ofiar Getta), istniał już w XVI w. i w wieku XIX rozrósł się do powierzchni niemal dwóch hektarów. Jeszcze przed pierwszą wojną światową zaprzestano na nim pochówków. Lokalizacja i otoczenie ceglanym murem rodziło niemałe kłopoty komunikacyjne, co spowodowało jego podział drogą przelotową (dziś ul. Jana III Sobieskiego) ${ }^{25}$. Już w miesiąc po zajęciu miasta przez Niemców w 1939 r. władze okupacyjne nakazały „uporządkowanie” cmentarza, co oznaczało wyburzenie okalającego go muru oraz systematyczne wywożenie macew. Były one używane przeważnie do utwardzania miejskich ulic (głównie ul. Szopena) ale nie tylko. Jak pisał obserwator tych poczynań: „Na ten cel szły przede wszystkim nagrobki piaskowcowe. Granitowe i marmurowe władze sprzedawały kamieniarzom, którzy cenne płyty przerabiali na nagrobki katolic-

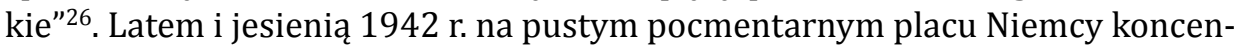
trowali Żydów przed marszem do wagonów na stację Staroniwa, skąd pociągi z ofiarami odchodziły do ośrodka zagłady w Bełżcu. Pierwszym aktom likwidacji getta towarzyszyła niezwykła brutalność i liczne mordy dokonywane przez funkcjonariuszy policji i SS ${ }^{27}$.

Podobny los spotkał nowszy z cmentarzy na Czekaju, po wschodniej stronie Wisłoka. Powstał on w połowie XIX w., gdy zaczęło brakować miejsca na pochówki na starym cmentarzu. Podczas wojny Niemcy wykorzystywali jego teren dla doraźnych mordów, co dokonywało się rękami funkcjonariuszy lokalnej pla-

${ }^{22}$ Wójcik, Rzeszów w latach drugiej wojny światowej..., s. 161.

${ }^{23}$ Jan Basta, Mniejszości narodowe na Rzeszowszczyźnie 1944-1946, „Prace Historyczno-Archiwalne", t. 2, 1994, s. 183-184.

${ }^{24}$ Jan Tomasz Gross, Strach. Antysemityzm w Polsce tuż po wojnie. Historia moralnej zapaści, Kraków: Znak, 2008, s. 78-84; Krzysztof Kaczmarski, Pogrom, którego nie było. Rzeszów, 11-12 czerwca 1945 r. Fakty, hipotezy, dokumenty, Rzeszów: Instytut Pamięci Narodowej, 2008.

${ }^{25}$ Franciszek Kotula, Tamten Rzeszów, Rzeszów: Mitel, 2003, s. 446. Wacław Wierzbieniec, Cmentarze żydowskie w Rzeszowie, „Zeszyty Naukowe Wyższej Szkoły Pedagogicznej w Rzeszowie" 1990, Seria Społeczno-Pedagogiczna i Historyczna, z. 1, s. 119-125.

${ }^{26}$ Kotula, Tamten Rzeszów..., s. 428-430.

${ }^{27}$ Moshe Oster, Gehinom znaczy piekło. Przeżyłem getto i dziewięć obozów, Kraków: Wydawnictwo Uniwersytetu Jagiellońskiego, 2013, s. 99-104 
cówki Gestapo, i grzebania ofiar. Oddalenie od centrum nie ocaliło cmentarza przed dewastacją, choć jej skala była nieco mniejsza niż w przypadku starego cmentarza. Macewy z nowej nekropolii wykorzystywano m.in. do utwardzenia koryta rzeki. Ocalało wiele podstaw macew, które pozwalają domyśleć się lokalizacji miejsc pochówku ${ }^{28}$.

Niewiele lepszy był los rzeszowskich synagog. Tzw. mała synagoga (staromiejska) istniała już na początku XVII w. Była wówczas częścią systemu obronnego miasta, co wiązało się z wyznaczeniem społeczności żydowskiej zadania obrony fragmentu murów ${ }^{29}$. Kilkakrotnie ulegała zniszczeniu podczas pożarów i najazdów na miasto, co skutkowało silnymi ingerencjami w pierwotną formę architektoniczną ${ }^{30}$. Ostatniej przebudowy dokonano w 1905 i w 1934 r. budynek wpisano do rejestru zabytków kultury ${ }^{31}$. Tuż po wkroczeniu Niemców została zdemolowana, a później urządzono w niej skład mebli po deportowanych do obozów zagłady. To spowodowało, że - jak pisał tuż po wojnie Franciszek Kotula - „zachowała się we względnie dobrym stanie i jest do odbudowania” ${ }^{32}$. W gorszym stanie przetrwała natomiast duża synagoga (tzw. nowomiejska). Zbudowana na początku XVIII $\mathrm{w}^{33} \mathrm{z}$ upływem lat przechodziła liczne przeobrażenia $^{34}$. Także ona została w $1939 \mathrm{r}$. zdewastowana, przeznaczona na magazyn i przed opuszczeniem miasta w 1944 r., podpalona ${ }^{35}$.

Inne miejsca związane z życiem rzeszowskich Żydów zniknęły z miejskiego krajobrazu lub - jeśli przetrwały w stosunkowo dobrym stanie - zostały szybko zaadoptowane do nowych potrzeb. Będący symbolem wkładu Żydów w życie kulturalne miasta - powstały w latach 1926-1928 Żydowski Dom Kultury - przetrwał wojnę jako Dom Żołnierza Niemieckiego. Zniszczeniu uległa natomiast umieszczona w nim bogata biblioteka ${ }^{36}$. Na topograficznej mapie Rzeszowa pojawiły się $\mathrm{w}$ okresie wojny nowe przestrzenie, świadczące teraz nie o życiu Żydów w mieście, lecz o ich cierpieniu i śmierci.

${ }^{28}$ Wacław Wierzbieniec, Cmentarze żydowskie w Rzeszowie, „Zeszyty Naukowe Wyższej Szkoły Pedagogicznej w Rzeszowie" 1990, Seria Społeczno-Pedagogiczna i Historyczna, z. 1, s. $123-125$.

${ }^{29}$ Adam Przyboś, Rzeszów na przełomie XVI i XVII wieku [w:] Pięć wieków miasta Rzeszowa XIV-XVIII, red. Franciszek Błoński, Warszawa: Polskie Towarzystwo Historyczne Oddział w Rzeszowie, Państwowe Wydawnictwo Naukowe, 1958, s. 98-99.

${ }^{30}$ Jan Pęckowski, Dzieje miasta Rzeszowa do końca XVIII wieku, Rzeszów 1913, s. 123.

${ }^{31}$ Maria Piechotka, Kazimierz Piechotka, Bramy nieba. Bóżnice murowane na ziemiach dawnej Rzeczypospolitej, Warszawa: Polski Instytut nad Sztuką Świata, Muzeum Historii Żydów Polskich, 2017, s. 206-210.

${ }^{32}$ Franciszek Kotula, Z dziejów Rzeszowa 1939-1944, Rzeszów, 1947, s. 61.

${ }^{33}$ Pęckowski, Dzieje miasta Rzeszowa do końca XVIII wieku, s. 123-124.

${ }^{34}$ Piechotka, Piechotka, Bramy nieba..., s. 362-366.

${ }^{35}$ Kotula, Z dziejów Rzeszowa 1939-1944..., s. 61.

${ }^{36}$ Marzena Lorens, Powstanie żydowskiego Domu Ludowego im. Adolfa Tanenbauma w Rzeszowie, „Z Przeszłości Rzeszowa” 2014, t. 5, s. 89-97. 


\section{Okres PRL - konsekwentne wymazywanie pamięci}

Analiza źródeł i publikacji dokumentujących proces odbudowy i przekształceń przestrzennych Rzeszowa po 1944 r. wskazuje, że nowi włodarze miasta w ogóle nie rozważali prób przywrócenia i wkomponowania pozostałości żydowskiego życia w strukturę przestrzenną miasta $\mathrm{w}$ ich pierwotnym znaczeniu. Nie było to zresztą potrzebne po ucieczce z miasta ostatnich Żydów w czerwcu 1945 r. Obecność ruin żydowskich synagog generowała problem, co z nimi zrobić. „Oczyszczone” przestrzenie cmentarzy stanowiły wręcz okazję do nowego wykorzystania, zwłaszcza w obliczu szansy na ukształtowanie nowego miasta socjalistycznego zgodnie z zamysłami i wzorcami adoptowanymi z ZSRR. Wobec tych niezwykłych materialnych świadków niedawno unicestwionej przeszłości podejmowano zatem różne działania, które realizowały dwie strategie.

Pierwsza $\mathrm{z}$ nich polegała na całkowitym wymazaniu z przestrzeni miejsc związanych z historią Żydów. Los taki spotkał najstarszy w mieście cmentarz zlokalizowany w centrum. Tuż po wojnie zamierzano na jego terenie urządzić trawnik ${ }^{37}$. Niedługo potem plac pocmentarny stał się miejscem szczególnego przedsięwzięcia architektonicznego. W jego centrum wybudowano w $1951 \mathrm{r}$. pomnik Wdzięczności Armii Radzieckiej zwrócony ku północy w stronę nowo wybudowanego gmachu KW PZPR. Nowa nazwa tak ukształtowanej przestrzeni (w latach 1952-1990 jako pl. Zwycięstwa) ostatecznie wymazywała przeszłość, czyniąc z placu modelowy obiekt nowego miasta socjalistycznego. Wykorzystano tym samym wcześniejsze dewastacyjne poczynania Niemców. Podobną strategię przedsięwzięto wobec licznych miejsc związanych z życiem i zagładą Żydów. Adaptacja na nowe cele w połączeniu z brakiem jakichkolwiek upamiętnień skutecznie wymazała ślady żydowskiej przeszłości.

Druga strategia polegała na rekonstrukcji miejsc ważnych z punktu widzenia żydowskiej historii i zaadoptowania ich do zupełnie nowych potrzeb. Obiekty miały pozostać w pejzażu miasta, lecz bez przesadnego podkreślania, jaka historia była z nimi związana. Tę ścieżkę postępowania wybrano w przypadku obu synagog i cmentarza na Czekaju ${ }^{38}$. Decyzję taką podjęto nie ze względu na znaczenie dla zachowania żydowskiej kultury, a jedynie przez wzgląd na status zabytków. W 1948 r. wspólna komisja członków Żydowskiej Kongregacji Religijnej i Wojewódzkiego Komitetu Żydowskiego podczas rozmów z prezydentem miasta postanowiła zachować obie synagogi ze względu na ich zabytkowy cha-

${ }^{37}$ Kazimierz Urban, Cmentarze żydowskie, synagogi i domy modlitwy w Polsce $w$ latach 1944-1966 (wybór materiałów), Kraków: Zakład Wydawniczy Nomos, 2006, s. 296.

${ }^{38}$ Los cmentarza na Czekaju także nie był z początku pewny. W piśmie Komendy Wojewódzkiej Milicji w Krakowie do Prezydium Wojewódzkiej Rady Narodowej w Rzeszowie z końca lat pięćdziesiątych czytamy: „Na cmentarzu żydowskim w Rzeszowie, przy ul. Rejtana [...] pasą się krowy i gęsi, a halę pogrzebową na tym cmentarzu zamieniono na stajnię dla krów, a to za zezwoleniem władzy terenowej, która ma nawet za to pobierać pewną opłatę" (ibidem, s. 537). 
rakter. Zaznaczono jednocześnie, że gdyby nie było to możliwe ze względu na stan zniszczenia synagogi nowomiejskiej, należy zachować przynajmniej synagogę staromiejską. Dokumentujące to spotkanie pismo kończy się znamiennym stwierdzeniem: „Sądzimy, że Zarząd Miejski w Rzeszowie powinien przyczynić się również pewną kwotą pieniężną do pokrycia koniecznych inwestycji, zwłaszcza że ten Zarząd wywłaszczył wiele nieruchomości żydowskich, jak nas poinformowano, bez odszkodowania, na cele miejskie" 39 .

Odbudowa synagog nie odbywała się bezkonfliktowo. Szczególnie skomplikowany był w tym względzie los starej synagogi (staromiejskiej). Choć z wojny wyszła w stosunkowo najlepszym stanie (z wyjątkiem zdewastowanego wnętrza), brak opieki w pierwszych latach powojennych zaowocował jej znaczną degradacją. Wycięcie przez złodziei zimą 1946/1947 r. wiązania dachowego i wiosenna wichura 1947 r. spowodowały zawalenie się dachu i sklepień. Próbujący interweniować w tej sprawie kustosz Muzeum Miasta Rzeszowa usłyszał: „nie ma Żydów, nich ginie i bożnica"40. W 1949 r. CKŻP poinformowała Ministerstwo Administracji Publicznej, że wyraża zgodę, by synagogę przejął rzeszowski oddział Związku Polskich Artystów Plastyków ${ }^{41}$. Nowy właściciel nie interesował się zupełnie budynkiem (stan synagogi znów się pogorszył), co zaowocowało w 1951 r. uchyleniem decyzji o przekazaniu gmachu ZPAP i przyznaniu go Archiwum Państwowemu, w którego posiadaniu miał pozostać przez kolejne 65 lat $^{42}$. W opisie sporządzonym podczas przekazania możemy przeczytać, jaki był stan budynku: „brak dachów, drzwi i okien, schody zbite i przegniłe - stan zniszczenia 75 procent" ${ }^{\prime 3}$. Podczas późniejszych remontów zachowano mury zewnętrzne, lecz zlikwidowano bramę. Podzielono sale na dwie kondygnacje oraz przebudowano dach, wbudowując trzecią kondygnację na poddaszu ${ }^{44}$.

Synagoga nowomiejska przetrwała wojnę w stanie daleko posuniętego zniszczenia. Zarząd Miejski skłaniał się ku wyburzeniu murów, czemu dał wyraz w następującej opinii: „Budynek jest dziś faktycznie ruiną, może i romantyczną i nie wadziłaby [ona] nikomu, gdyby stała na uboczu. Ale właśnie stoi w jednym z najruchliwszych punktów miasta [...] Stała się niebezpieczna i Zarząd Miejski, który odpowiada za bezpieczeństwo w mieście, musi przystąpić do jej zburzenia" ${ }^{45}$. Stan budynku był tak zły, że jego los nie był zgoła pewny. Ostatecznie synagoga została odbudowana w latach 1954-1963. Towarzyszyła temu gruntowna przebudowa, która zmieniła w dużym stopniu jej pierwotny kształt. Zrekonstruowany budynek stał się siedzibą Biura Wystaw Artystycznych ${ }^{46}$.

\footnotetext{
${ }^{39}$ Ibidem, s. 296-297.

${ }^{40}$ Ibidem, s. 295.

${ }^{41}$ Ibidem, s. 297.

42 Ibidem, s. 298.

${ }^{43}$ Ibidem, s. 299-300.

${ }^{44}$ Piechotka, Piechotka, Bramy nieba..., s. 210.

${ }^{45}$ Urban, Cmentarze żydowskie..., s. 295.

${ }^{46}$ Piechotka, Piechotka, Bramy nieba..., s. 366.
} 
W przeciwieństwie do obszaru pocmentarnego ukrytego pod trawnikami i alejkami placu Zwycięstwa, na którym nie umieszczono nawet najmniejszej informacji, co znajdowało się na jego terenie, budynki synagog przypominały o swojej przeszłości głównie formą odróżniającą się od okolicznego pejzażu. W latach sześćdziesiątych XX w. na zewnętrznej, północnej ścianie synagogi nowomiejskiej znalazła się informacja, że był to budynek synagogi zniszczony przez hitlerowców i został „odbudowany przez PWRN [...] dla rozwoju i upowszechnienia sztuki w województwie".

\section{Okres niepodległości - mozolne przywracanie pamięci}

Upadek komunizmu przyniósł wzrost zainteresowania przeszłością unicestwionych przez Niemców lokalnych społeczności żydowskich. Nie inaczej było w Rzeszowie, choć porównując bogactwo żydowskiej przeszłości z zakresem nowych form jej upamiętniania, zabiegi te należy określić jako stosunkowo skromne. Nadal nieznaczna jest skala upamiętnień jakie w latach 1989-2021 starały się przywróciły pamięć o rzeszowskich Żydach w przestrzeni symbolicznej miasta. Pojawiły się w tym czasie dwie cykliczne uroczystości towarzyszące obchodom Międzynarodowego Dnia Pamięci o Ofiarach Holocaustu oraz rocznicy likwidacji rzeszowskiego getta. Szczególne znaczenie ma ta ostatnia uroczystość, ze względu na swój bardzo lokalny charakter organizowana zawsze 7 lipca, w rocznicę pierwszej i najbardziej krwawej deportacji do Bełżca.

Z pewnością najbardziej jaskrawym przejawem wojennego niszczenia i powojennego zamazywania pamięci o rzeszowskich Żydach był pl. Zwycięstwa. W 1990 r. nadano mu nową nazwę - pl. Ofiar Getta. Niestety, przez ponad dekadę nie towarzyszyło temu żadne dodatkowe upamiętnienie. Zdecydowana większość spacerujących po placu mieszkańców nadal nie była świadoma, że pod alejkami znajduje się najstarsza żydowska nekropolia Rzeszowa. W $2004 \mathrm{r}$. Mirosław Kędzior i Janusz Korbecki wystąpili z wnioskiem projektu pomnika Kamienia Pamięci, przypominającego o istnieniu w tym miejscu cmentarza oraz dramacie deportacji do Bełżca w $1942 \mathrm{r}$. W tymże roku projekt zyskał wstępną akceptację prezydenta Rzeszowa. Wnioskodawcy określili pl. Ofiar Getta jako „Umschlagplatz żydowskich mieszkańców Rzeszowa i okolic”. Pisali: „Sądzimy, że miejsce to jest miejscem niezwykłym i wyjątkowym na mapie miasta Rzeszowa. Pragnieniem naszym jest postawienie «kamienia-pomnika» przywracającego pamięć wielu pokoleniom Żydów, mieszkańców Rzeszowa, którzy razem z innymi obywatelami współtworzyli historię miasta" ${ }^{47}$. Pomnik odsłonięto w lipcu $2005 \mathrm{r}$.

Ponadto zadecydowano o wmurowaniu w ściany budynków obu synagog dodatkowych tablic informacyjnych, ponieważ znajdujących się na nich informacji

${ }^{47}$ Informacje na podstawie dokumentacji Komitetu Ochrony Pamięci Walk i Męczeństwa przy Wojewodzie Podkarpackim w Rzeszowie, Wydział Polityki Społecznej Urzędu Wojewódzkiego w Rzeszowie. 
w żaden sposób nie można było uznać za wystarczające i stosowne. W $1998 \mathrm{r}$. na synagodze staromiejskiej odsłonięto dodatkową tablicę podpisaną przez Związek Żydów Rzeszowa w Izraelu i miasto Rzeszów, ku „pamięci Żydów ziemi rzeszowskiej - ofiar hitleryzmu". Głównym elementem tablicy jest przełamana menora oraz cytat ( $w$ języku polskim, hebrajskim i angielskim) pochodzący z Księgi Jeremiasza $(8,23)$ : „Bym mógł dniem i nocą opłakiwać zabitych Córy mojego ludu". Kilka lat później na obu synagogach pojawiły się też zaprojektowane według tego samego formatu i znacznie większe tablice z podkreśleniem znaczenia miejsc synagog dla pamięci ofiar Holokaustu. Obie informują, że synagogi zostały zbezczeszczone przez okupanta i upamiętniają „20 000 Żydów z Rzeszowa i okolic zamordowanych w latach 1939-1945 przez niemieckich ludobójców". W październiku 2021 r. na ścianie synagogi pojawiła się także tablica ku pamięci urodzonego w Rzeszowie Dawida Altera Kurzmanna (1878-1942), opiekuna żydowskich sierot zamordowanego w Bełżcu razem z podopiecznymi.

Między 1989 a 2021 r. nie zmienił się status gmachu synagogi nowomiejskiej. Nadal jest on siedzibą Biura Wystaw Artystycznych. Zmiana zaszła natomiast w statusie własnościowym budynku synagogi staromiejskiej, opuszczonego jesienią 2016 r. przez Archiwum Państwowe (przeniesiono je do nowo wybudowanej siedziby na ul. W. Warneńczyka) i przekazanego Gminie Wyznaniowej Żydowskiej w Krakowie. Opuszczony budynek został wynajęty Urzędowi Miasta w Rzeszowie i pełni ponownie funkcję archiwum, tym razem miejskiego.

Nie zawsze proces upamiętnień przebiegał bezproblemowo. Kontrowersje wywołała pamiątkowa tablica w dawnym Żydowskim Domu Kultury, który po wojnie przejściowo pełnił funkcję Teatru Ziemi Rzeszowskiej, a w 1953 r. stał się siedzibą Wojewódzkiego Domu Kultury Związków Zawodowych ${ }^{48}$.

Pomysł upamiętnienia działalności organizacji syjonistycznych $\mathrm{w}$ byłym Żydowskim Domu Kultury im. Tannenbauma pojawił się w 2002 r. i wyszedł od ówczesnego sekretarza światowego Ruchu „Hanoar Hzioni” Arie Edelheita. Analiza dokumentacji Wydziału Polityki Społecznej Urzędu Wojewódzkiego w Rzeszowie wskazuje, że sprawa została rozpatrzona stosunkowo szybko, a sama idea znalazła powszechną akceptację wszystkich instancji odpowiedzialnych za procedurę upamiętnień, od Rzeszowa po Warszawę ${ }^{49} .21$ czerwca 2004 r. odbyła się uroczystość odsłonięcia tablicy. Uczestniczyli w niej goście z Izraela i USA, przedstawiciele „Hanoar Hatzioni”, m.in. ambasador Izraela oraz przedstawiciele władz państwowych i samorządowych (drugi wicewojewoda, wiceprezydent miasta).

W niespodziewany sposób tablica stała się przedmiotem ostrego ataku ze strony posła na sejm Zygmunta Wrzodaka, działacza Ligi Polskich Rodzin, który w październiku 2004 r. wystosował na ręce ministra spraw wewnętrznych i ad-

\footnotetext{
${ }^{48}$ Lorens, Powstanie żydowskiego Domu Ludowego im. Adolfa Tanenbauma..., s. 89-97.

${ }^{49}$ Informacje na podstawie dokumentacji Komitetu Ochrony Pamięci Walk i Męczeństwa przy Wojewodzie Podkarpackim w Rzeszowie, Wydział Polityki Społecznej Urzędu Wojewódzkiego w Rzeszowie.
} 
ministracji Ryszarda Kalisza ostry i obszerny treściowo protest, domagając się jej usunięcia. W piśmie poseł zawarł swoje rozważania na temat historii Żydów od czasów, gdy „legiony Rzymu rozproszyły ludność prowincji żydowskiej po całej Europie” i nawiązywał szeroko do tzw. Judeo-Polonii. Napisał m.in.: „W obecności lokalnych władz i przedstawicieli społecznych upamiętniono działania na terenie Polski organizacji, która chętnie dokonałaby całkowitej likwidacji tejże, a przynajmniej ograniczenia polskiej suwerenności i niepodległości terytorialnej. Trudno znaleźć przykład podobnego upamiętnienia antypolskości nawet w czasach PRL". Interpelacja nie przyniosła skutku. Zaowocowała natomiast dyskusją nad stroną estetyczną tablicy, którą poddano krytyce. W wywiadzie dla

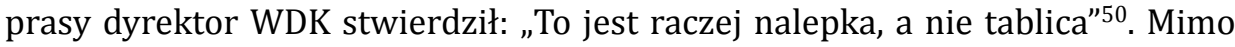
kontrowersji i wątpliwości co do jakości wykonania tablica do dziś znajduje się w holu budynku.

Rzeszowscy Żydzi i ich historia są upamiętniane także przez dwie szczególne cykliczne uroczystości. Pierwsza z nich - marsz - została zapoczątkowana 7 lipca 2003 r., w 65. rocznicę likwidacji getta. Ma charakter oddolny, została zainicjowana poza instytucjami kulturalno-edukacyjnymi miasta. Organizator marszu, Mirosław Kędzior, tak opisywał jego początki:

Była nas zaledwie garstka. Razem z Januszem Korbeckim i kilkoma znajomymi wzięliśmy transparent z gwiazdą Dawida i poszliśmy z placu Ofiar Getta na dworzec Staroniwa. Tą samą trasą, którą ponad 20000 rzeszowskich Żydów wyruszyło w podróż do obozów zagłady. W czasie kolejnych marszów odwróciliśmy trasę, żeby symbolicznie odwrócić ten marsz śmierci na marsz żywych [...] Ludzie byli chyba trochę zszokowani naszym widokiem. Szliśmy z gwiazdą Dawida, a nie byliśmy grupą Żydów. Taka sytuacja się jeszcze w Rzeszowie nie zdarzyła. Ale nie przypominam sobie, żeby wtedy pod naszym adresem padały jakieś wyzwiska. Zdarzało się to w czasie kolejnych marszów. Kiedyś grupka szalikowców robiła nam zdjęcia ${ }^{51}$.

W marszu każdego roku uczestniczy od kilkudziesięciu do ponad stu osób. „Były takie lata - wspominał Mirosław Kędzior - że było nas bardzo dużo, ale znów jest nas grupka"52. Najważniejszymi uczestnikami marszu są ocalali z Zagłady: Moshe Oster (w latach 2006-2008), Mieczysław Winogórski (2006-2008) i Judit Elkin (w latach 2006-2018). W marszu uczestniczyli także Konstanty Gebert (2006), Monika Krawczyk (2006), Piotr Kadlcik (2009), Michael Schudrich $(2013)^{53}$. Pojawiają się również przedstawiciele władz miasta oraz rzeszow-

\footnotetext{
${ }^{50}$ Janusz Koryl, Gorqca tablica, „Dzień Rzeszowa”, 17 II 2005.

${ }^{51}$ Anna Gorczyca, Trzeba przypominać, że żyli tu Żydzi, Rozmowa z Mirosławem Kędziorem, współorganizatorem Marszów Pamięci, „Gazeta Wyborcza”, 6 VII 2012.

${ }^{52}$ Ibidem.

${ }^{53}$ Anna Gorczyca, Marsz pamięci, „Gazeta Wyborcza”, 8-9 VII 2006; Lucyna Szura, Tych drzew tu nie było, były kamienie i dużo krwi, „Gazeta Wyborcza”, 9 VII 2007; Anna Gorczyca, Rzeszów wciqż̇ pamięta, „Gazeta Wyborcza”, 7 VII 2008; Marsz tych, którzy pamiętają o Ho-
} 
skich instytucji (w tym IPN), choć okolicznościowe przemówienie (w postaci listu prezydenta miasta) zawsze jest podobnej treści i najbardziej podkreśla wspólnotę cierpienia Polaków i Żydów. Zdaniem Magdaleny Prokopowicz i Wacława Wierzbieńca: „Władze podkreślają jedność ofiary Polaków i Żydów oraz heroizm poświęcenia Polaków dla ratowania Żydów"54. W 2019 r. między organizatorami marszu a Instytutem Pamięci Narodowej doszło do konfliktu o nazwę marszu. IPN zwrócił uwagę, że nazwa uroczystości (Marsz Upamiętniający Haniebną Likwidację Getta Żydowskiego w Rzeszowie) nie zawiera informacji, kto był twórcą getta i kto dokonał jego likwidacji. Zarzut ten spowodował natychmiastową decyzję organizatorów o zaprzestaniu organizowania marszu.

Z punktu widzenia pamięci samych mieszkańców Rzeszowa, najważniejsze wydają się motywacje uczestnictwa w tym wydarzeniu. Dla najstarszych wynikają z żywej pamięci przedwojennych czasów, co oddaje zarejestrowana przez prasę wypowiedź uczestnika:

Wtedy, w lipcu 1942 roku, miałem pięć lat, ale pamiętam dworzec na Staroniwie. Byłem tam z babcią niedługo po tym, jak Niemcy wywieźli Żydów. Zobaczyłem strażaków, którzy pompowali wodę. Zapytałem babci, czy oni podlewają kwiatki, odpowiedziała mi, że zmywają krew. Gdy szliśmy ulicami, babcia mówiła mi: tędy szły takie dzieci jak ty [...]. Pomyślałem sobie, że przejdę tę trasę i oddam hołd babci i tym ludziom, którzy zginęli ${ }^{55}$.

W przypadku osób młodych i w średnim wieku motywacje mają charakter bardziej moralny, wynikający z potrzeby pamięci o niewinnie zgładzonych i odpowiedzi na pojawiające się współczesne akty antysemityzmu: „Uważam, że powinniśmy oddać hołd tysiącom ludzi, którzy zostali zamordowani. I pokazać, że taki marsz może się odbyć w Rzeszowie, gdzie zdarzają się przypadki antysemityzmu"56. W 2005 r. przy okazji marszu odsłonięto Kamień Pamięci. Podczas pobytu w Rzeszowie Moshe Oster stwierdził: „Ten kamień jest ważniejszy dla was, dla Polaków, nie dla nas, ale cieszę się, że tam jest" ${ }^{57}$.

Drugą uroczystością upamiętniającą rzeszowskich Żydów jest Międzynarodowy Dzień Pamięci o Ofiarach Holocaustu. Pierwsza taka uroczystość odbyła się w 2009 r. Program uroczystości każdego roku jest podobny, z tym zastrzeżeniem, że systematycznie rośnie zakres obchodów organizowanych poza Rzeszowem na całym Podkarpaciu oraz wzrasta liczba towarzyszących im im-

lokauście, „Gazeta Wyborcza. Rzeszów”, 6 VII 2009, Marsz pamięci; „Gazeta Wyborcza”, 5 VII 2010; Anna Gorczyca, Pamiętaja o rzeszowskich Żydach, „Gazeta Wyborcza”, 11 VII 2011; Będziemy pamiętać, „Gazeta Wyborcza”, 11 VII 2016.

${ }^{54}$ Magdalena Prokopowicz, Wacław Wierzbieniec, Pamięć o Holocauście na Podkarpaciu na początku XXI wieku na przykładzie uroczystości rocznicowych, „Studia Podlaskie” 2017, t. 24 , s. 202.

${ }^{55}$ Anna Gorczyca, Pamiętają o rzeszowskich Żydach, „Gazeta Wyborcza”, 11 VII 2011.

${ }^{56}$ Eadem, Marsz pamięci, „Gazeta Wyborcza”, 8-9 VII 2006.

${ }^{57}$ Eadem, Marsz tych, co pamiętaja i chca pamiętać, „Gazeta Wyborcza”, 6 VII 2006. 
prez. W Rzeszowie każdego roku organizowane są uroczystości na żydowskim cmentarzu na Czekaju, podczas których odmawiany jest kadisz (wielokrotnie w uroczystości brał udział rabin Shalom Dov Ber Stambler), a w Uniwersytecie Rzeszowskim oraz w innych instytucjach w mieście organizuje się wystawy, prelekcje i spotkania ${ }^{58}$. W 2019 r. uroczystościom towarzyszyło wręczenie doktoratu Honoris Causa Uniwersytetu Rzeszowskiego prof. Shimonowi Redlichowi. W 2021 r. ze względu na stan pandemii imprezy towarzyszące rocznicy odwołano, a organizatorzy zaapelowali o zapalenie symbolicznego znicza w miejscach związanych z Holokaustem na terenie całego województwa.

\section{Żydzi i ich przeszłość w świadomości mieszkańców miasta}

Wnioskowanie o pamięci jakiejkolwiek wspólnoty wyłącznie na podstawie liczby materialnych upamiętnień oraz uczestnictwa jej mieszkańców w rocznicowych uroczystościach mówi o stanie tej pamięci jedynie część prawdy. Kluczowe pytania, które badacz tej tematyki musi postawić, brzmią: W jakim stopniu przeszłość Żydów znajduje odzwierciedlenie w świadomości mieszkańców? Co wiedzą oni o tej przeszłości i jakie postawy wobec niej przyjmują? Czy materialne pamiątki pozostałe po Żydach w miejskiej przestrzeni są w ogóle przez mieszkańców identyfikowane z ich historią? Czy są w stanie wywoływać u nich jakiekolwiek emocje, czy też są jedynie obojętnie mijanym elementem krajobrazu?

W 2010 i 2015 r. Instytut Socjologii Uniwersytetu Rzeszowskiego we współpracy z Urzędem Miasta zrealizował dwa sondaże na reprezentatywnej, adresowej próbie mieszkańców wylosowanej z bazy mieszkańców Urzędu Miasta. Oba sondaże wykonano w ramach realizowanego cyklicznie przez instytut Rzeszowskiego Sondażu Społecznego, tym razem pod nazwą „Rzeszowscy Żydzi w świadomości mieszkańców miasta Rzeszowa". W 2010 r. kwestionariusze wywiadu wypełniło 585 mieszkańców Rzeszowa, do których wyruszyli studenci socjologii UR. W 2015 r. badanie powtórzono i tym razem kwestionariusze wywiadu wypełniło 800 mieszkańców miasta.

W świetle zebranych danych empirycznych można stwierdzić, że wiedza mieszkańców Rzeszowa o przeszłości zamieszkujących miasto Żydów jest marginalna. W 2010 r. niemal 70 procent respondentów nie potrafiło wskazać żadnego miejsca związanego z życiem społeczności żydowskiej na terenie miasta przed drugą wojną światową. W 2015 r. odsetek ten zwiększył się do niemal 73 procent. W $2010 \mathrm{r}$. niemal 78 procent respondentów nie umiało wymienić miejsca związanego z cierpieniami i zagładą Żydów na obszarze Rzeszowa. W 2015 r. skala niewiedzy na ten temat sięgnęła niemal 85 procent. Co szczególnie znamienne, w 2015 r. ponad 87 procent respondentów nie potrafiło wskazać żadnego upamiętnionego miejsca związanego z życiem rzeszowskich Żydów w przestrzeni miasta.

${ }^{58}$ Program Dnia Pamięci o Ofiarach Holocaustu, „Gazeta Wyborcza”, 27 I 2009. 
Wyniki dotyczące wiedzy na temat odsetka Żydów zamieszkujących miasto przed wojną i ofiar Zagłady okazały się tylko niewiele lepsze. W pierwszym przypadku brak wiedzy zadeklarowało 50,5 procent w 2010 r. i 60,8 procent w 2015 r. W drugim z tych pytań odsetki wyniosły: 57,9 procent w 2010 r. i 66 procent w 2015 r. Analiza danych empirycznych wskazuje, że większość udzielonych odpowiedzi i tak była niepoprawna. Tym samym, na podstawie badań można stwierdzić, że w Rzeszowie jedynie w przypadku maksymalnie 1/5 mieszkańców możemy mówić o niewielkiej (przeważnie bardzo powierzchownej) wiedzy o najbardziej elementarnych aspektach historii Żydów zamieszkujących miasto. Znaczny poziom wiedzy jest udziałem śladowego odsetka badanych. Większość mieszkańców nie ma żadnej wiedzy lub „wiedza” ta jest niepoprawna i niezgodna z ustaleniami historycznymi.

Analiza udzielonych odpowiedzi (zarówno poprawnych, jak i niepoprawnych) pozwala na sformułowanie kilku wniosków, które wydają się ważne z punktu widzenia praktyki i ewentualnych działań edukacyjnych na przyszłość. Odnośnie do miejsc związanych z życiem społeczności żydowskiej na terenie miasta przed drugą wojną światową $w$ udzielonych odpowiedziach dominowała przestrzeń dwóch synagog (wskazywanych przez 9,7 i 15,2 procent respondentów w 2010 i 2015 r.). Wiele odpowiedzi było mało precyzyjnych i odnosiło się do okolic Rynku, co znajduje pewne usprawiedliwienie w tym, że rzeczywiście były to obszary tętniącego żydowskiego życia. Drugie miejsce pod względem wskazań zajął cmentarz na Czekaju (w 2015 r. wymieniony przez 10,1 procent respondentów). Co znamienne, śladowe były wskazania na najstarszą, choć już nieistniejącą przestrzeń starego cmentarza na pl. Ofiar Getta. Równie śladowe były odsetki wskazań (0,5 w 2010 r. i 0,4 procent w 2015 r.) na Dom Kultury fundacji Tannenbauma (dziś Wojewódzki Dom Kultury na ul. Okrzei).

Większe problemy mieli respondenci z wymienieniem miejsc związanych z cierpieniami i zagładą Żydów na terenie Rzeszowa. Pierwsze miejsce przypadło obszarowi getta (13,5 procent wskazań w 2010 r. i 8,2 procent w 2015 r.), choć pewne znaczenie ma zapewne znajdująca się na jego terenie nazwa placu, wskazująca wyraźnie na wojenny kontekst zdarzeń. Bardzo ograniczona jest niestety świadomość, jaką rolę odegrał dworzec kolejowy Staroniwa, skąd odchodziły wagony towarowe wypełnione rzeszowskimi Żydami do komór gazowych w Bełżcu. Miejsce to wskazało w 2015 r. zaledwie 1,1 procent respondentów.

Skłaniającymi do smutnej refleksji powinny być wyniki odpowiedzi na pytanie o upamiętnione miejsca związane z życiem rzeszowskich Żydów. W 2015 r. zaledwie 6,7 procent respondentów wymieniło cmentarz na Czekaju, 4,6 procent pl. Ofiar Getta a 2,7 procent synagogi. Tak śladowa skala wiedzy na najbardziej upamiętnionych przestrzeniach związanych z żydowską historią miasta wskazuje na bardzo słaby rezonans materialnych form pamięci i na obojętność w momencie kontaktu z przestrzeniami, które nawet pod względem architektonicznym odróżniają się dość wyraźnie w pejzażu miasta. 
Podsumowując wyniki badań nad polskim antysemityzmem, Andrzej Żbikowski zauważył: „Respondenci, mimo że są świadomi swej niewielkiej wiedzy o Żydach, formułują sądy na ich temat bardzo śmiało i jednoznacznie orzekająco" ${ }^{\prime \prime}$. W sondażach na mieszkańcach Rzeszowa zaobserwowano podobne zjawisko. Zadano rzeszowianom serię pytań o wkład Żydów w życie Rzeszowa przed drugą wojną światową na polu np. kultury, handlu, nauki i polityki. Zauważono znamienne zjawisko. 0 ile o udziale Żydów w życiu społeczno-politycznym miasta nie potrafiło nic powiedzieć 60-70 procent respondentów, o tyle o wkładzie w handel miejski już tylko 30-55 procent.

Choć wiedza o żydowskiej historii miasta jest niewielka, wkład Żydów w jego historię oceniany był raczej pozytywnie. Najlepsze oceny sformułowano w odniesieniu do prowadzonego przez nich handlu miejskiego $(62,6$ procent pozytywnych ocen w 2010 i 41,2 procent w 2015 r.) oraz rozwoju kultury, nauki i szkolnictwa (44,7 i 42,2 procent w 2010, 28,5 i 24,6 procent w 2015 r.). Najmniej pozytywne noty uzyskała działalność Żydów w polityce miejskiej $(29,6$ procent w 2010 r. i 21,5 procent w 2015 r.). W obliczu marginalnej wiedzy o historii rzeszowskich Żydów wyniki te można zapewne traktować bardziej jako ocenę ich obecności na różnych płaszczyznach życia społeczno-gospodarczego. Nie sposób przeoczyć obecności stereotypów i uproszczeń, zwłaszcza powszechnego utożsamiania Żydów z handlem.

Ponieważ historia jest nieodłącznym elementem współczesności, politycznych debat, materialnej spuścizny w postaci miejsc pamięci, przenoszonych z pokolenia na pokolenie antagonizmów i uprzedzeń, poproszono respondentów o wyrażenie opinii na temat wpływu relacji polsko-żydowskich i Holokaustu na współczesne podejście do upamiętniania wspólnej przeszłości. Porównując badania z 2010 i 2015 r. można zauważyć, że zmalała znacząco akceptacja dla pomysłu powołania muzeum historii rzeszowskich Żydów. W sondażu z $2010 \mathrm{r}$. niemal 59 procent respondentów zgodziło się ze stwierdzeniem, że w Rzeszowie powinna powstać placówka muzealna upamiętniająca Żydów związanych $\mathrm{z}$ tym miastem. Idei takiej sprzeciwiło się 18,4 procent, a 22,7 nie miało zdania. Po pięciu latach 31,6 procent poparło taką inicjatywę, 27,2 procent było jej przeciwnych, 41,2 procent nie miało wyrobionej opinii. Z wynikami tymi korespondują odpowiedzi na pytanie, czy w promocji Rzeszowa należy eksponować przeszłość Żydów zamieszkujących niegdyś w mieście. W 2010 r. 41,9 procent respondentów poparło taki postulat. Pięć lat później odsetek ten zmalał do 30,7 procent. Zwiększył się natomiast udział osób przeciwnych - z 23,8 procent w 2010 r. do 27,2 procent w 2015 r.

W świetle przywoływanych badań warto zwrócić także uwagę na wyobrażenie mieszkańców Rzeszowa na ogólną naturę relacji polsko-żydowskich w okresie przedwojennym i podczas okupacji. W 2015 r. 40,7 procent poddanych badaniu rzeszowian wyraziło pogląd, że przed wojną Polacy i Żydzi żyli w Rzeszowie

\footnotetext{
${ }^{59}$ Ibidem, s. 86.
} 
na ogół bezkonfliktowo (10,8 procent nie zgodziło się z tym, a 48,5 procent nie miało zdania). Ponad połowa badanych (54,5 procent) zgodziło się z opinią, że podczas wojny większość Polaków starała się pomagać Żydom (przeciwnego zdania było 7,4 procent respondentów, a 38,1 procent nie miało zdania w tej kwestii). Wyniki te wskazują, że Rzeszów nie odbiega od „średnich” ogólnopolskich wyobrażeń o relacjach polsko-żydowskich, w których Druga Rzeczypospolita jawi się jako okres bez antysemityzmu, wojna zaś to czas powszechnego pomagania żydowskim sąsiadom.

Podsumowując tę część rozważań, należy podkreślić, że sondaż z 2010 r. odtworzył elementy wyobrażeń o przeszłości Żydów z pewnym udziałem wspomnień osób, które pamiętały Żydów z własnego doświadczenia. W sondażu z 2015 r. struktura wiekowa respondentów uległa „przesunięciu”, a udział osób, które osobiście miały kontakt z rzeszowskimi Żydami, zmalał do śladowego rozmiaru.

\section{Zakończenie}

Jak zatem podsumować zaprezentowane wyniki badań nad pamięcią przeszłości rzeszowskich Żydów? Z pewnością nie można powiedzieć, że Rzeszów jest obszarem społecznego zapomnienia o swojej żydowskiej przeszłości, definiowanego jako celowe działania mającego na względzie usunięcie określonych treści (tu przeszłości Żydów) ze pamięci zbiorowej ${ }^{60}$. Nie potwierdzałaby tego analiza przestrzeni symbolicznej miasta - upamiętniającego historię Żydów $\mathrm{w}$ stopniu wprawdzie nieznacznym, lecz ostatecznie pozwalająca osobie z zewnątrz wyrobić sobie pewien obraz dawnej, unicestwionej przeszłości. Bardziej problematyczne jest określenie zakresu zapomnienia w świadomości samych mieszkańców. Nie jesteśmy w stanie stwierdzić bez kolejnych pogłębionych badań, na ile w świadomości mieszkańców występuje proces celowego zaniechania wspomnień o tym aspekcie historii lub wypierania go ze świadomości. To zjawisko ze sfery psychologii pozostaje nadal wyzwaniem naukowym. Tym trudniejszym, że kolejne przedsięwzięcie badawcze byłoby realizowane już wyłącznie wśród osób, z których żadna nie pamiętałaby Żydów z indywidualnego doświadczenia.

Nie można także powiedzieć, że Rzeszów jest społeczną przestrzenią sprzyjającą pamięci o tak kluczowej części swej przeszłości, jaką jest historia jego dawnych żydowskich mieszkańców. Wszystkie przestrzenie, które wykorzystywała żydowska społeczność miasta, zagospodarowano na nowe potrzeby. Najważniejszego miejsca cierpień rzeszowskich Żydów - stację Staroniwa do dziś nie oznacza żaden ślad pozwalający przechodniowi się dowiedzieć, że

${ }^{60}$ Marta Karkowska, Filip Pazderski, Zapomnienie [w:] Modi memorandi. Leksykon kultury pamięci, red. Magdalena Saryusz-Wolska, Robert Traba, Warszawa: Wydawnictwo Naukowe Scholar, 2014, s. 545-546. 
było to ostatnie miejsce w Rzeszowie, które przed Zagładą widzieli jego dawni żydowscy obywatele. W mieście nie ma do dziś żadnej instytucji muzealnej zajmującej się tym aspektem przeszłości (nie licząc pewnej ilości eksponatów w Muzeum Okręgowym). Opuszczona przez Archiwum Państwowe, licząca sobie ponad 400 lat synagoga staromiejska, nadawałaby się niewątpliwie do tego najlepiej. Należy jednak pamiętać, że z punktu widzenia pracy nad pamięcią ważna jest nie tyle sama instytucja muzeum, ile raczej forma, w jakiej przekazuje ona swoje przesłanie. Dlatego celowe byłoby powołanie nie placówki gromadzącej i eksponującej eksponaty, ale bardziej miejsca „żywej pamięci”, łączącej przez genius loci interdyscyplinarną edukację z wydarzeniami kulturalnymi nie tylko przywracającymi żydowską przeszłość, lecz także ukazującymi jej znaczenie dla współczesnego miasta i tożsamości jego mieszkańców.

Silna pamięć o Żydach z pewnością istnieje, jest jednak domeną nielicznej grupy osób, co potwierdzają najjaskrawiej lipcowe marsze pamięci lub styczniowe uroczystości na cmentarzu na Czekaju. Jest to pamięć ekskluzywna, należąca do nielicznych jednostek. Dla nich ważna i zasługująca za cenę wysiłku na przekazywanie kolejnym pokoleniom.

Można w tym miejscu zaryzykować twierdzenie, że w przestrzeni społecznej miasta występuje znacząca luka dotycząca ważnego elementu jego przyszłości. Nie jest to zjawisko nieodwracalne i nie oznacza całkowitej utraty wiedzy o tym fragmencie historii. Wszystkie nośniki służące przywróceniu tej pamięci tkwią w przestrzeni miasta, są „na wyciągnięcie ręki” i wystarczy tylko po nie sięgnąć. Jednakże nie ma ku temu jak na razie woli decydentów politycznych, gdyż prawdopodobnie podobne działania $\mathrm{z}$ ich strony nie byłyby pozytywnie odebrane przez mieszkańców. Zjawiska takie określane są w naukach społecznych jako niepamięć ${ }^{61}$. Przeszłość Żydów nie jest wprawdzie negowana, niszczona lub cenzurowana, ale znajduje się na marginesie pamięci dynamicznie rozwijającej się stolicy województwa. Nadal czeka na swój moment, czas przywołania, gdy zostanie jej przywrócone należne miejsce w zbiorowej pamięci wspólnoty.

\section{BIBLIOGRAFIA}

Antysemityzm, Holokaust, Auschwitz w badaniach społecznych, red. Kucia Marek, Kraków: Wydawnictwo Uniwersytetu Jagiellońskiego, 2011.

Basta Jan, Mniejszości narodowe na Rzeszowszczyźnie 1944-1946, „Prace Historyczno-Archiwalne", t. 2, 1994.

Będziemy pamiętać, „Gazeta Wyborcza”, 11 VII 2016.

Bieda Tadeusz, Eksterminacja Żydów w Rzeszowie w latach 1939-1944, „Prace Historyczno-Archiwalne" 1993, t. 1.

Fishman Samuel, Dean Martin, Rzeszów [w:] Encyclopedia of Camps and Ghettos 19331945, t. 2: Ghettos In German-Occupied Eastern Europe, red. Martin Dean, Mel Hecker, Bloomington-Indianapolis: United States Holocaust Memorial Museum, Indiana University Press, , 2012.

${ }^{61}$ Piotr T. Kwiatkowski, Zapomnienie [w:] Modi memorandi..., s. 545-550. 
Gorczyca Anna, Marsz pamięci, „Gazeta Wyborcza”, 8-9 VII 2006.

Gorczyca Anna, Marsz tych, co pamiętają i chca pamiętać, „Gazeta Wyborcza”, 6 VII 2006. Gorczyca Anna, Pamiętaja o rzeszowskich Żydach, „Gazeta Wyborcza”, 11 VII 2011.

Gorczyca Anna, Rzeszów wciąż pamięta, „Gazeta Wyborcza”, 7 VII 2008.

Gorczyca Anna, Trzeba przypominać, że żyli tu Żydzi, Rozmowa z Mirosławem Kędziorem, współorganizatorem Marszów Pamięci, „Gazeta Wyborcza”, 6 VII 2012.

Gross Jan T., Strach. Antysemityzm w Polsce tuż po wojnie. Historia moralnej zapaści, Kraków: Znak, 2008.

Kaczmarski Krzysztof, Pogrom, którego nie było. Rzeszów, 11-12 czerwca 1945 r. Fakty, hipotezy, dokumenty, Rzeszów: Instytut Pamięci Narodowej, 2008.

Kapralski Sławomir, Żydzi i zagłada w polskich kulturach pamięci: między antagonizmem i agonem, „Teksty Drugie” 2016, nr 6.

Karkowska Marta, Filip Pazderski, Zapomnienie [w:] Modi memorandi. Leksykon kultury pamięci, red. Magdalena Saryusz-Wolska, Robert Traba, Warszawa: Wydawnictwo Naukowe Scholar, 2014.

Koryl Janusz, Gorąca tablica, „Dzień Rzeszowa”, 17 II 2005.

Kotula Franciszek, Z dziejów Rzeszowa 1939-1944, Rzeszów, 1947.

Kotula Franciszek, Tamten Rzeszów, Rzeszów: Mitel, 2003.

Krakowski Shmuel, Rzeszów [w:] Encyclopedia of the Holocaust, red. Israel Gutman, New York-London: Macmillan Publishing Company, Collier Macmillan Publishers, 1990.

Kuwałek Robert, Obóz zagłady w Bełżcu, Lublin: Państwowe Muzeum na Majdanku, 2010.

Kwiatkowski Piotr T., Lech M. Nijakowski, Barbara Szacka, Andrzej Szpociński, Między codziennościq a wielka historiq̨. Druga wojna światowa w pamięci zbiorowej społeczeństwa polskiego, Gdańsk-Warszawa: Muzeum II Wojny Światowej, Wydawnictwo Naukowe Scholar, 2010.

Kwiatkowski Piotr T., Zapomnienie [w:] Modi memorandi. Leksykon kultury pamięci, red. Magdalena Saryusz-Wolska, Robert Traba, Warszawa: Wydawnictwo Naukowe Scholar.

Le Goff Jacques, Historia i pamięć, tłum. Anna Gronowska, Joanna Stryjczyk, Warszawa: Wydawnictwa Uniwersytetu Warszawskiego, 2007.

Lehmann Rosa, Symbiosis and Ambivalence. Poles and Jews in a small Galician Town, Oxford-New York: Berghahn Books, 2001.

Lorens Marzena, Powstanie żydowskiego Domu Ludowego im. Adolfa Tanenbauma w Rzeszowie, „Z Przeszłości Rzeszowa” 2014, t. 5.

Malicki Krzysztof, 70 lat po Zagładzie. Przeszłość Żydów w pamięci zbiorowej mieszkańców Rzeszowa, Rzeszów: Wydawnictwo Uniwersytetu Rzeszowskiego, 2016.

Krzysztof Malicki, Poza wspólnota pamięci. Życie i Zagłada Żydów w pamięci mieszkańców regionu podkarpackiego, Warszawa: Wydawnictwo IFiS PAN, 2017.

Marsz pamięci, „Gazeta Wyborcza”, 5 VII 2010.

Marsz tych, którzy pamiętajq̨ o Holokauście, „Gazeta Wyborcza. Rzeszów”, 6 VII 2009.

Nowak Jacek, Sławomir Kapralski, Dariusz Niedźwiedzki, On the banality of forgetting: tracing the memory of Jewish culture in Poland, Berlin: Peter Lang, 2018.

Oster Moshe, Gehinom znaczy piekło. Przeżyłem getto i dziewięć obozów, Kraków: Wydawnictwo Uniwersytetu Jagiellońskiego, 2013.

Pęckowski Jan, Dzieje miasta Rzeszowa do końca XVIII wieku, Rzeszów 1913.

Piechotka Maria, Kazimierz Piechotka, Bramy nieba. Bóżnice murowane na ziemiach dawnej Rzeczypospolitej, Warszawa: Polski Instytut nad Sztuką Świata, Muzeum Historii Żydów Polskich, 2017. 
Program Dnia Pamięci o Ofiarach Holocaustu, „Gazeta Wyborcza”, 27 I 2009.

Prokopowicz Magdalena, Wacław Wierzbieniec, Pamięć o Holocauście na Podkarpaciu na początku XXI wieku na przykładzie uroczystości rocznicowych, „Studia Podlaskie” 2017, t. 24.

Przyboś Adam, Rzeszów na przełomie XVI i XVII wieku [w:] Pięć wieków miasta Rzeszowa XIV-XVIII, red. Franciszek Błoński, Warszawa: Polskie Towarzystwo Historyczne Oddział w Rzeszowie, Państwowe Wydawnictwo Naukowe, 1958.

Rączy Elżbieta, Zagłada Żydów w dystrykcie krakowskim w latach 1939-1945, Rzeszów: Instytut Pamięci Narodowej - Uniwersytet Rzeszowski, 2014.

Redlich Shimon, Razem i osobno. Polacy, Żydzi, Ukraińcy w Brzeżanach 1919-1945, tłum. Grzegorz Godlewski, Sejny: Pogranicze 2002.

Rzeszów, Kraków: Wydawnictwo Artystyczno-Graficzne 1965.

Rzeszów [w:] The Encyclopedia of the Jewish Life before and during the Holocaust, red. Shmuel Spector, Geoffrey Wigoder, Elie Wiesel, t. 2, New York: New York University Press, 2001.

Schnür-Pepłowski Stanisław, Galiciana 1772-1812, Lwów: Księgarnia H. Altenberga, 1896.

Sułek Antoni, Badacz i świadek drugiej generacji. O ratowaniu lokalnej pamięci zagłady Żydów, „Więź” 2017, nr 4 (670).

Sułek Antoni, Zwykli Polacy patrza na Żydów. Postawy społeczeństwa polskiego wobec Żydów w świetle badań sondażowych (1967-2008) [w:] Następstwa zagłady Żydów. Polska 1944-2010, red. Feliks Tych, Monika Adamczyk-Garbowska, Lublin: UMCS, Żydowski Instytut Historyczny, 2011.

Szacka Barbara, Czas przeszły, pamięć, mit, Warszawa: Wydawnictwo Naukowe Scholar, 2006.

Szacka Barbara, Pamięć społeczna [w:] Encyklopedia socjologii, Warszawa: Oficyna Naukowa, 2000.

Szura Lucyna, Tych drzew tu nie było, były kamienie i dużo krwi, „Gazeta Wyborcza”, 9 VII 2007.

Tokarska-Bakir Joanna, Legendy o krwi. Antropologia przesqdu, Warszawa: Wydawnictwo W.A.B., 2008.

Urban Kazimierz, Cmentarze żydowskie, synagogi i domy modlitwy w Polsce $w$ latach 1944-1966 (wybór materiałów), Kraków: Zakład Wydawniczy Nomos, 2006.

Wierzbieniec Wacław, Cmentarze żydowskie w Rzeszowie, „Zeszyty Naukowe Wyższej Szkoły Pedagogicznej w Rzeszowie" 1990, Seria Społeczno-Pedagogiczna i Historyczna, z. 1.

Wierzbieniec Wacław, Z dziejów gminy żydowskiej w Rzeszowie, „Prace Historyczno-Archiwalne" 1995, t. 3.

Wierzbieniec Wacław, Rzeszów [w:] The Yivo Encyclopedia of Jews in Eastern Europe, red. Gershon David Hundert, t. 1, New Haven-London, Yale University Press, 2008.

Witalec Robert, Historia Żydów Rzeszowskich od XVI wieku do 1944 roku, „Prace Historyczno-Archiwalne" 1993, t. 1.

Wójcik Zbigniew K., Rzeszów w latach drugiej wojny światowej. Okupacja i konspiracja 1939-1944-1945, Rzeszów-Kraków: Instytut Europejskich Studiów Społecznych, 1998.

Young James E., The Texture of Memory. Holocaust, Memorials and Meaning, New Haven London: Yale University Press, 1993. 
